\title{
UNA IGLESIA CON ROSTRO MAPUCHE
}

\section{Hna. Audina Huenumilla}

Como mujer mapuche que ha optado por consagrar su vida al interior de una congregación religiosa, me siento profundamente parte de la Iglesia e igualmente, consciente de pertenecer a un Pueblo con una cultura diferente. Pienso que, desgraciadamente, en la Iglesia no hemos hecho un esfuerzo real por inculturarnos en las categorias de mi pueblo. La Iglesia permanece distante de él en sus expresiones litúrgicas, organizativas y disciplinarias. Por ello, qué le pediría yo a la Iglesia:

Que desde una mayor cercanía con nuestro Pueblo, la Iglesia asumiera con mayor dinamismo y compromiso nuestro proyecto histórico. Qué su voz profética se alzará con mayor fuerza en la defensa de nuestros derechos y de nuestra cultura.

Que la Iglesia ponga sus instituciones al servicio de la revalorización de nuestra cultura, sobre todo, colaborando con las comunidades mapuches, sean estas rurales o urbanas, en su organización y desarrollo.

Que la Iglesia asuma un compromiso con nuestra lengua. Que se hagan esfuerzos por anunciar la buena noticia de Jesús en nuestra propia lengua. Que los ministros aprendan la lengua. Que la Iglesia de nuestra Región asuma el bilingüismo como algo normal dentro de una comunidad pluricultural.

Que la liturgia pueda realizarse en nuestra lengua, con signos, cantos, instrumentos, danzas, etc., que respondan a nuestra realidad cultural. Que podamos celebrar a campo abierto, al aire libre, con un tiempo disponible para compartir entre hermanos, con espacio para el purrun y para escuchar la voz de nuestros sabios, loncos y machis, etc. Sólo así, la liturgia cristiana será una verdadera fiesta y una verdadera rogativa para los mapuches.

Que se valorice nuestra experiencia religiosa mapuche. Que nuestros hermanos y hermanas que acojan el Evangelio no se vean compelidos a renunciar arbitrariamente ni a su experiencia ni a su expresión religiosa. Aqui, creo que se hace urgente un verdadero diálogo interreligioso.

Que la Iglesia de pasos firmes hacia una catequesis que responda y valore la realidad cultural y religiosa de nuestro Pueblo, tomando en cuenta los momentos más importantes de la vida mapuche: el bautismo, el matrimonio, el Nguillatun, etc.

Que aquellos mapuches que nos hemos consagrado al servicio del Reino ya sea dentro de una congregación o a través del presbiterado, tengamos un espacio para encontrarnos y conversar sobre nuestra experiencia de fe. Que podamos expresarnos libremente en nuestro idioma. 